\title{
Climate change adaptation in European river basins
}

\author{
Patrick Huntjens · Claudia Pahl-Wostl • \\ John Grin
}

Received: 1 July 2008/Accepted: 24 December 2009/Published online: 2 February 2010

(c) The Author(s) 2010. This article is published with open access at Springerlink.com

\begin{abstract}
This paper contains an assessment and standardized comparative analysis of the current water management regimes in four case-studies in three European river basins: the Hungarian part of the Upper Tisza, the Ukrainian part of the Upper Tisza (also called Zacarpathian Tisza), Alentejo Region (including the Alqueva Reservoir) in the Lower Guadiana in Portugal, and Rivierenland in the Netherlands. The analysis comprises several regime elements considered to be important in adaptive and integrated water management: agency, awareness raising and education, type of governance and cooperation structures, information management and-exchange, policy development and-implementation, risk management, and finances and cost recovery. This comparative analysis has an explorative character intended to identify general patterns in adaptive and integrated water management and to determine its role in coping with the impacts of climate change on floods and droughts. The results show that there is a strong interdependence of the elements within a water management regime, and as such this interdependence is a stabilizing factor in current management regimes. For example, this research provides evidence that a lack of joint/participative knowledge is an important obstacle for
\end{abstract}

John Grin's work on this article was part of the programme of the Dutch Knowledge network on System Innovations (KSI).

P. Huntjens $(\bowtie) \cdot$ C. Pahl-Wostl

Institute for Environmental Systems Research,

University of Osnabruck, Barbarastraße 12, Geb. 66,

49069 Osnabruck, Germany

e-mail: patrickhuntjens@yahoo.com

J. Grin

Amsterdam School for Social Science Research,

University of Amsterdam, Amsterdam, The Netherlands cooperation, or vice versa. We argue that there is a twoway relationship between information management and collaboration. Moreover, this research suggests that bottom-up governance is not a straightforward solution to water management problems in large-scale, complex, multiple-use systems, such as river basins. Instead, all the regimes being analyzed are in a process of finding a balance between bottom-up and top-down governance. Finally, this research shows that in a basin where one type of extreme is dominant-like droughts in the Alentejo (Portugal) and floods in Rivierenland (Netherlands) - the potential impacts of other extremes are somehow ignored or not perceived with the urgency they might deserve.

Keywords Standardized comparative analysis . Adaptive and integrated water management (AIWM) . Water management regime - River basin management Climate change adaptation - Floods · Droughts . Hungary $\cdot$ Portugal $\cdot$ Netherlands $\cdot$ Ukraine

\section{Introduction}

The challenges posed by climate-related extreme events to river basins are manifold, especially since water resource issues interact with a wide range of environmental and socioeconomic sectors including health, public safety, agriculture, biodiversity, industry, navigation, and tourism. According to the Intergovernmental Panel on Climate Change (IPCC 2007), an increase in the surface temperature of water and changes in the hydrological cycle could result in changing rainfall patterns. Some areas may experience intense rainfall resulting in heavy floods, while other areas may witness less rainfall, and also frequent droughts. 


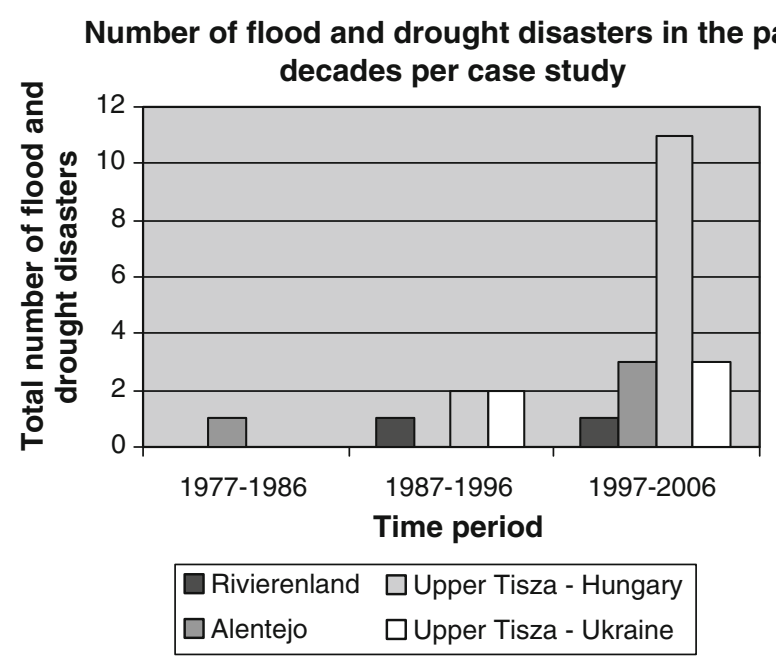

Fig. 1 Number of reported flood and drought disasters in the past decades in Rivierenland, Alentejo, Hungarian part of Upper Tisza, and Ukrainian part of Upper Tisza. Based on data from EM-DAT: The OFDA/CRED International Disaster Database 2008

On a global scale, the number of disasters caused by weather-related phenomena such as storms, floods, and droughts has more than doubled over the past decade, from 175 in 1996 to 391 in 2005 (IFRC 2008). The same trend (Fig. 1) is being observed in the case-studies under investigation, which is Rivierenland in the Netherlands, the Alentejo region (including the Alqueva reservoir) of the lower Guadiana River Basin in Portugal, the Hungarian part of the Upper Tisza, and the Ukrainian part of the Upper Tisza (also called the Zacarpathian Tisza).

Comparing data for the past decade (1997-2006) with data for the previous decade (1987-1996), the number of reported flood and drought disasters ${ }^{1}$ has increased (see Fig. 1). Over the same period, the average total number of people reported affected ${ }^{2}$ per decade rose by $1200 \%$, from approximately 38 thousand to 480 thousand. Meanwhile, the total cost of reported damage ${ }^{3}$ doubled, from US\$ 1.2 billion to US\$2.4 billion (2006 prices), although this could partially be explained by a higher density or vulnerability of infrastructure and areas being used by humans. Moreover, more detailed documentation of smaller disasters

\footnotetext{
${ }^{1}$ For a disaster to be entered into the Emergency Events Database (EM-DAT) at least one of the following criteria must be fulfilled: (1) Ten or more people reported killed; (2) Hundred people reported affected; (3) Declaration of a state of emergency; (4) Call for international assistance (From: EM-DAT 2008).

2 Total number of people affected: Sum of injured, homeless, and affected; Affected: People requiring immediate assistance during a period of emergency; it can also include displaced or evacuated people (From: EM-DAT 2008).

${ }^{3}$ Estimated Damage: Several institutions have developed methodologies to quantify these losses in their specific domain. However, there is no standard procedure to determine a global figure for economic impact (From: EM-DAT 2008).
}

partially explains the earlier mentioned increases. It shows nevertheless that flood and drought problems become more visible and cannot be ignored. Especially since climate change models project more frequent and intense summer droughts across many parts of Europe, particularly in the southern part (Goodess et al. 2007; Fowler et al. 2007). This may be further exacerbated because of an increasing demand for water as a result of elevated temperatures.

The increasing frequency and intensity of floods and droughts is also being confirmed by the latest report of the Intergovernmental Panel on Climate Change (IPCC, Fourth Assessment Report 2007), which argues that "there are multiple lines of evidence that climate change is happening now, and the impacts are being seen now". Given the expected increase of climate-related extreme events, water management capabilities in the case-studies, and on a global scale, will be tested to their limits by the effects of climate change. This requires innovative and adaptive ways of managing water, which can be referred to as "Adaptive and Integrated Water Management" (AIWM). This paper addresses the role of AIWM in coping with the impacts of climate change on floods and droughts in four case-studies in three European river basins. The explorative character of this paper intends to identify general patterns in the characteristics of AIWM and assumes that regimes with a higher level of AIWM consider and implement more advanced and a more diverse set of structural and nonstructural measures.

The selected case-studies are all confronted with floods and droughts. Even the most drought-prone case-study, the Alentejo Region in Portugal, was confronted with serious flooding events (notably in 1997 and 2006). Next to this similarity of being confronted with floods and droughts, the management regimes in all four case-studies are subject to a similar institutional setting on the European level [e.g. Water Framework Directive (Directive 2000/60/EC), Common Agricultural Policy, etcetera], except for the Ukrainian part of the Tisza. However, the Ukraine shows strong incentives to enter the EU community and thus the EU acquis communautaire is used as key reference for the development of its water management principles. It was nevertheless decided to select two case-studies in the Tisza Basin, because the international Tisza river basin is situated at the current borderline of the EU (e.g. Hungary and Ukraine) and thus the national and regional water management might follow different frameworks for the one river.

Despite the earlier mentioned similarities between the case-studies, it is expected ${ }^{4}$ that there are (substantial) differences between the water management regimes of

\footnotetext{
${ }^{4}$ Based on baseline assessments of the case-studies in the NeWaterproject (http://www.newater.info).
} 
these case-studies, more specifically in their level of AIWM. ${ }^{5}$ Therefore, this paper intends to identify differences and similarities in AIWM, to detect general patterns, and to compare measures being taken to cope with floods and droughts.

The characteristics (see next paragraphs) of AIWM are to be regarded as working hypotheses, since the change toward more adaptive management regimes is yet slow and empirical data and practical experience thus limited-in particular regarding the interdependence of elements of the management regime. The strong interdependence of the factors stabilizing current management regimes is also one possible reason for this lack of innovation. One cannot, for example, move easily from top-down to participatory management practices without changing the whole approach to information and risk management. Hence, research is urgently needed to better understand the interdependence of key elements of water management regimes and the dynamics of transition processes in order to be able to compare and evaluate alternative management regimes and to implement and support transition processes if required.

This article also addresses the question whether a higher level of AIWM is showing a different response in coping with floods and droughts than case-studies with a lower level of AIWM. This will be done by looking at their adaptation strategies and their planned or implemented physical interventions in the river basin.

This paper is focusing on conditions and processes in the management of a specific part of the river basin at sub national level (e.g. water boards), but being embedded in a wider context (e.g. institutional setting at different levels). The sub national level is conceived as the level where all elements of a water management regime are at play. At the same time, this level is influencing, or is being influenced by, higher and lower levels. This central position also allows for assessing the outcomes of a water management regime at the operational level, since the management on the sub-basin level (e.g. water board or regional water authority) is influenced by international or national regulation, while implementing at the operational/local level.

A calibrated approach (standardized questionnaires and interviews, expert judgment, and reinterpretation of outcomes by means of relevant literature) was used to compare the state of affairs in water management in the selected case-studies.

\footnotetext{
$\overline{5}$ For historical developments and institutional settings of the specific case-studies more information can be found in Huntjens et al. (2007), Chapter 4 of NeWater Deliverable 1.7.9a (http://www.newater.info).
}

\section{Adaptive and integrated water management}

Given the expected increase of climate-related extreme events, water governance capabilities in the case-studies, and on a global scale, will be tested to their limits by the effects of climate change. This requires innovative and adaptive ways of managing water, which can be referred to as "Adaptive and Integrated Water Management" (AIWM).

To deal with existing and new complexities, water resources management must be able to respond to changes in the natural and social environment and to anticipate associated uncertainties (Folke et al. 2005; Pahl-Wost et al. 2007). Adaptation to climate change and management of related risks should therefore be built into water resources management plans and programmes. Adaptive and integrated management is considered to be an appropriate approach for doing so. Adaptive and integrated management can be defined as a structured process for improving systemic management policies and practices by learning from the outcomes of implemented management strategies (Pahl-Wostl et al. 2007a). By re-evaluating goals, objectives and means how to achieve them as new information and insights become available, adaptive management is more responsive to changing conditions of and demands on ecosystems when compared to traditional approaches to water resource management.

AIWM requires different capabilities than traditional forms of water management, particularly when it comes to creating forms of collaboration between water managers and stakeholders, the relation between science and policy, the importance of participatory learning processes, dealing with uncertainty, and assessing a wide variety of possible measures and future scenario's. It requires many instances of social learning to implement and sustain innovative management approaches (Pahl-Wostl et al. 2007). Folke et al. (2005) already pointed out that social learning is needed to build up experience for coping with uncertainty and change. They emphasize that "knowledge generation in itself is not sufficient for building adaptive capacity in social-ecological systems to meet the challenge of navigating nature's dynamics" and conclude that "learning how to sustain social-ecological systems in a world of continuous change needs an institutional and social context within which to develop and act". Knowledge and the ability to act upon new insights are continuously enacted in social processes. The social network of stakeholders is an invaluable asset for dealing with change.

These considerations highlight that one important element of adaptive water management is the governance structure. Adaptive governance can be understood as the synthesis of collaborative management and adaptive management (Wailand 2006). It can be defined as the totality of 
interactions, by private and public actors, to achieve adaptation and to enhance the capacity of processes, institutional arrangements and actors to adapt to future environmental changes (Huitema et al. 2009). Adaptive governance depends on adaptive institutions (Pahl-Wostl 2002) that are able to cope with complexity and uncertainty and to face new challenges such as climate change.

However, in technology-dominated water management practice, design and structure of governance regimes has not played a prominent role. Adaptive and integrated water resources management implies a real paradigm shift in water management from what can be described as a prediction and control to a management as learning approach. Such change aims at increasing the adaptive capacity of river basins at different scales and implies a change in the whole water management regime (Pahl-Wostl 2007; Adger et al. 2005). Some structural requirements for a water management regime to be adaptive are summarized in Table 1. Two different regimes characterized by two different management paradigms-management as control versus management as learning-are contrasted as the extreme, opposing ends of six axes.

\section{Interdependence of the regime characteristics and responsiveness to floods and droughts}

The key objective of our research is to see whether there is a link between regime characteristics and responsiveness to floods and droughts (as an output of the regime at play). For this purpose, we needed to develop two different and independent analytical frameworks:

- A framework for assessing the characteristics of a water management regime

- A framework for assessing responsiveness to floods and droughts

In the next paragraphs, we will provide the conceptual background for both frameworks and related development of variables and indicators.

\section{A framework for assessing the characteristics of a water management regime}

For this purpose, we first needed to develop a normative framework of how an adaptive and integrated management regime looks like, in order to develop indicators for assessing the regime characteristics. For this normative framework, we have used the working hypotheses on the characteristics of AIWM being presented in Table 1. These working hypotheses have been further developed into a methodology for evaluating the level of Adaptive and
Integrated Water Management, which resulted in an analytical framework for assessing regime characteristics, consisting of nine different dimensions of variables:

1. Agency

2. Awareness Raising \& Education

3. Type of governance

4. Cooperation structures

5. Policy development \& implementation

6. Information management \& sharing

7. Finances and cost recovery

8. Risk management

9. Effectiveness of (international) regulation

As a useful starting point for operationalization, we considered the River Basin Assessment framework developed by Raadgever et al. (2008). Raadgever et al. developed a framework including four regime elements (4-7). Based on relevant literature (see endnotes in Table 2), we have added the dimensions agency, governance, awareness raising and education, risk management, and effectiveness of (international) regulation to the four regime elements that Raadgever et al. (idem) used to describe a management regime in their article. Furthermore, we have developed variables and indicators for the added dimensions and adjusted some of the variables and indicators in the framework of Raadgever et al. (2008). By doing so, we have further developed the methodology for assessing and comparing governance regimes. The operationalization resulted in 33 variables; comprising 62 indicators (see Table 2, including related literature). In addition to the framework of Raadgever et al. (2008), we have provided a more detailed explanation and related literature for each indicator in order to prevent ambiguity in the interpretation of indicators.

The current large number of variables is inherent to the explorative character of this research, but also to the nature of complex (governance) systems. Hence, one cannot simply omit variables without eroding the comprehensiveness of our analysis of complex governance systems. In other words, with our current number of variables, we consciously intended to reduce the risk of glossing over potential key variables, especially since the empirical base for AIWM is yet rather weak, and we cannot a priori justify which variables should be in or out.

\section{A framework for assessing responsiveness to floods and droughts}

A second analytical framework, independent from the first one, has been developed for assessing the responsiveness to floods and droughts in river basins, being defined as physical adaptation measures within the context of flood 
Table 1 Different regimes and their characteristics (From: Pahl-Wostl et al. 2007a)

\begin{tabular}{|c|c|c|}
\hline Dimension & Prediction, control regime & Integrated, adaptive regime \\
\hline Governance & Centralized, hierarchical, narrow stakeholder participation & Polycentric, horizontal, broad stakeholder participation \\
\hline $\begin{array}{l}\text { Sectoral } \\
\text { integration }\end{array}$ & $\begin{array}{l}\text { Sectors separately analyzed resulting in policy conflicts and } \\
\text { emergent chronic problems }\end{array}$ & $\begin{array}{l}\text { Cross-sectoral analysis identifies emergent problems and } \\
\text { integrates policy implementation }\end{array}$ \\
\hline $\begin{array}{l}\text { Scale of analysis } \\
\text { and operation }\end{array}$ & $\begin{array}{l}\text { Transboundary problems emerge when river sub-basins are } \\
\text { the exclusive scale of analysis and management }\end{array}$ & $\begin{array}{l}\text { Transboundary issues addressed by multiple scales of } \\
\text { analysis and management }\end{array}$ \\
\hline $\begin{array}{l}\text { Information } \\
\text { management }\end{array}$ & $\begin{array}{l}\text { Understanding fragmented by gaps and lack of integration of } \\
\text { information sources that are proprietary }\end{array}$ & $\begin{array}{l}\text { Comprehensive understanding achieved by open, shared } \\
\text { information sources that fill gaps and facilitate integration }\end{array}$ \\
\hline Infrastructure & $\begin{array}{l}\text { Massive, centralized infrastructure, single sources of design, } \\
\text { power delivery }\end{array}$ & $\begin{array}{l}\text { Appropriate scale, decentralized, diverse sources of design, } \\
\text { power delivery }\end{array}$ \\
\hline Finances and risk & $\begin{array}{l}\text { Financial resources concentrated in structural protection } \\
\text { (sunk costs) }\end{array}$ & $\begin{array}{l}\text { Financial resources diversified using a broad set of private } \\
\text { and public financial instruments }\end{array}$ \\
\hline
\end{tabular}

protection and drought/low flow protection. The type of measures listed in this framework (see Tables 4 and 5) are drawn from two different reports. The first one is a report of the European Environment Agency called 'Climate change and water adaptation issues' (EEA Technical Report No 2/2007), the second report is called the 'Bouwstenen Nota' (RIZA 2007), which is a study describing all potential flood protection measures in Dutch Rivers. The current status of physical interventions in each case-study has been assessed by means of expert judgment (see methodology in the next paragraph).

In principle, the measures themselves might have been implemented very recently or decades ago. Moreover, it should be taken into account that these management regimes may be currently evolving as a response to climate-related extreme events. In other words, even when a new management regime has been established, it may not have achieved its projected outcomes yet. For this reason, the responsiveness of the management systems in the case-studies to extreme events as presented here should be viewed as a snapshot, especially since there normally is a time lag between policy development and implementation of measures. This time lag has been taken into account in this research by asking experts to indicate whether measures are (1) already implemented (=physically present), (2) being planned, or (3) necessary, but not being planned (yet). Nevertheless, the results presented in this research are not able to indicate: (a) whether the implemented measures are working properly or whether their quality and scale is sufficient to deal with the problems they are designed for; (b) if, how and when the planned measures will be really implemented and whether there will be complications during implementation (e.g. delays, insufficient funds, and objection by citizen groups.), and (c) measures which are necessary, but have not been planned yet, could be planned after all in the nearby future. Hence, it is important to monitor the responsiveness of the management regimes in these casestudies for a longer period and on a frequent basis.
Apart from the physical intervention in the water system, a regime's performance could and should also be measured by its management interventions, such as awareness campaigns, measures for improving information management and exchange, cooperation structures, and insurance mechanisms. The assessment of management interventions is beyond the scope of this paper, but has been taken into account in succeeding research of EU NeWater.

\section{Methodology}

A calibrated approach using a standardized questionnaire for the elements of AIWM, and a questionnaire for physical interventions in the river basin (see Tables 4 and 5), expert judgment for both questionnaires, and reinterpretation of outcomes by means of relevant literature was used to compare the water management regimes in the selected case-studies.

By combining in-depth case-studies with more extensive and formal comparative analysis, we can to some extent use the strengths of one method to compensate for limitations inherent in the other. This explorative research has taken the research problem, rather than a favorite methodology, to determine the research approach, and both the quantitative and qualitative aspects have been and can be used in a consonant manner (de Leon 1998). As such it is possible to combine the qualities of the case-oriented approach with the qualities of the variable-oriented approach (Berg-Schlosser et al. 2008). In this research, expert judgment has been used as method for knowledge elicitation on regime elements and internal processes. The list of potential respondents for each case-study was developed in cooperation with the case-study teams of NeWater, with the objective of selecting a group of respondents with enough knowledge on the case-study under consideration and with the ability to answer the 


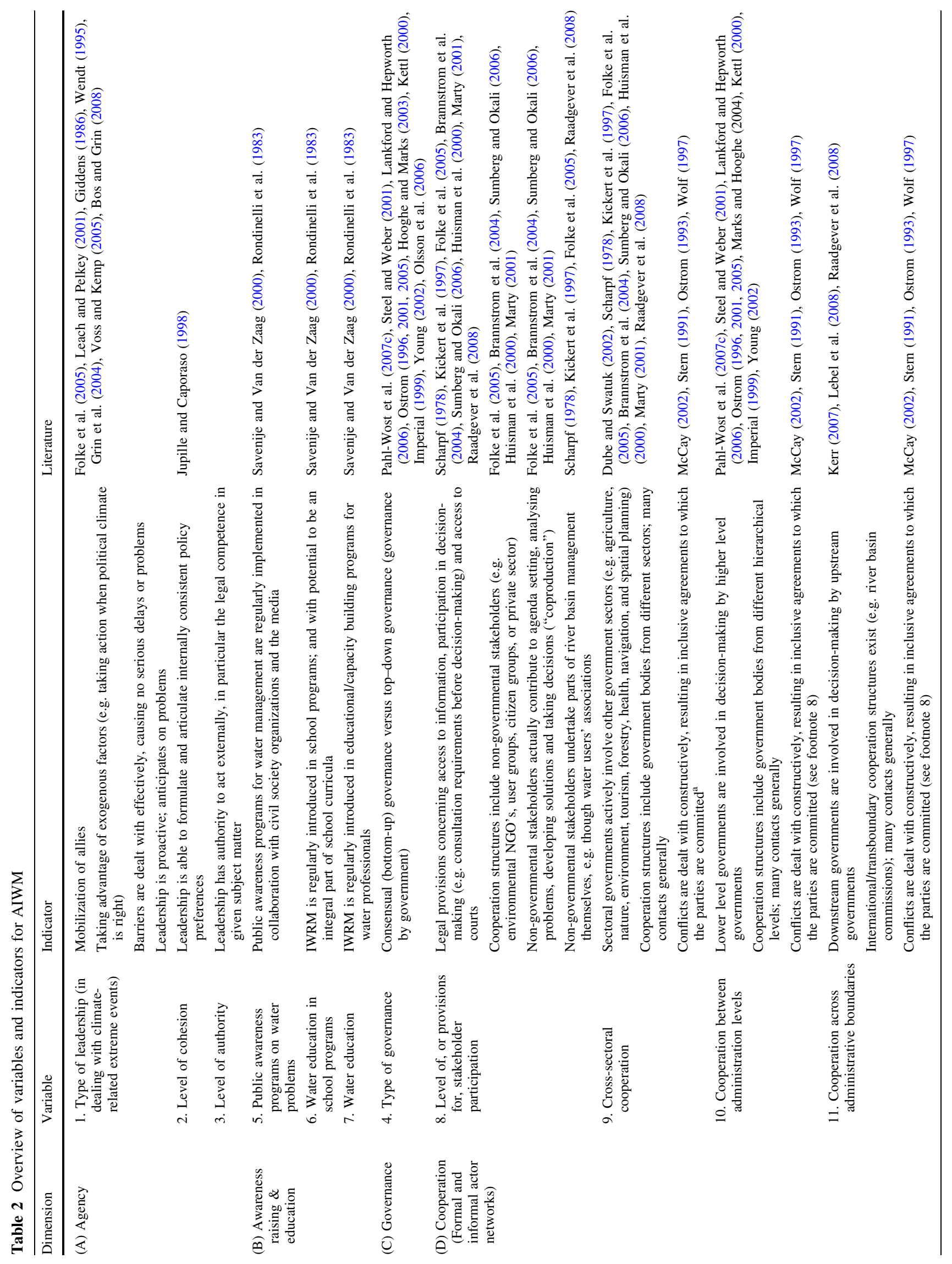




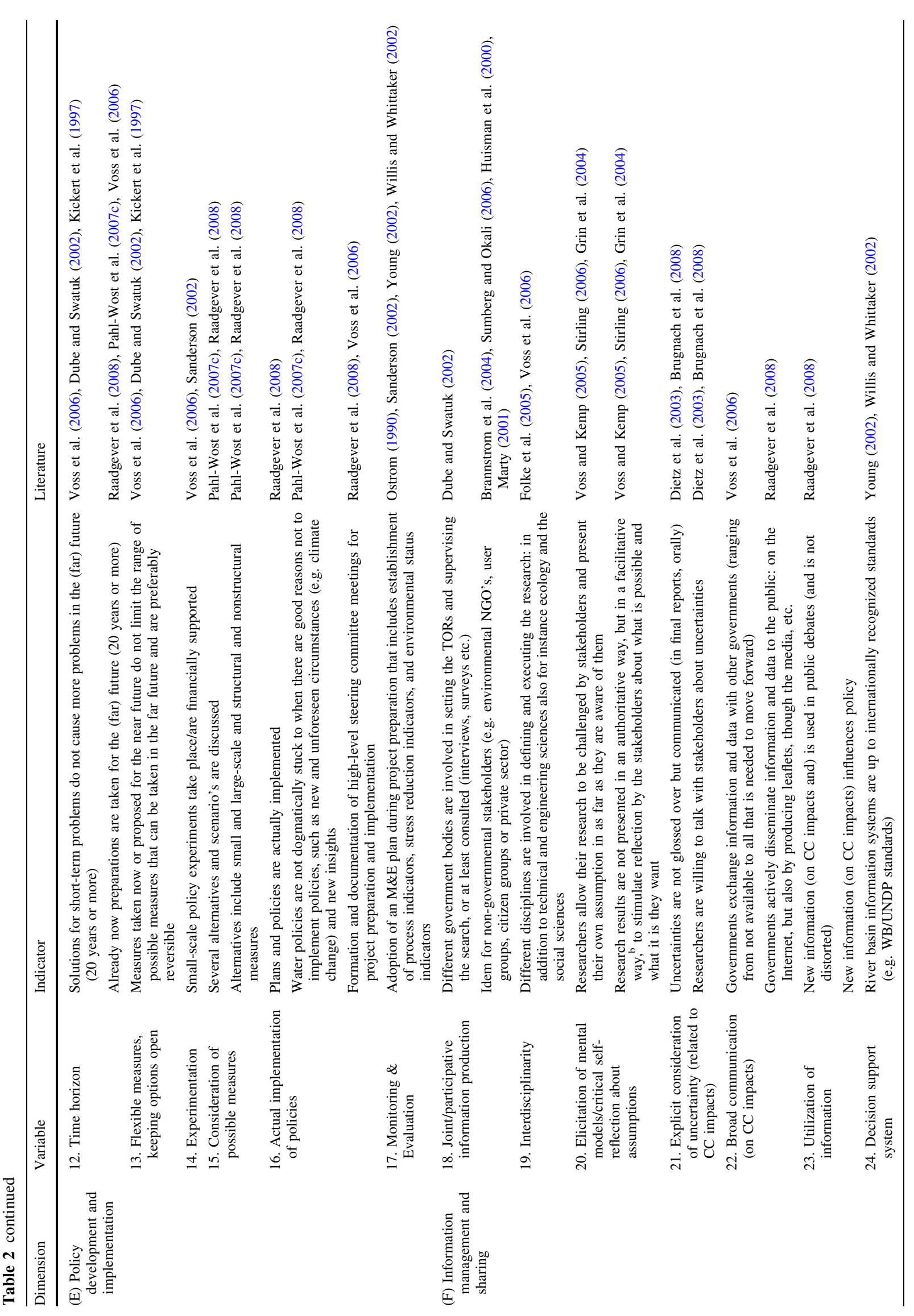




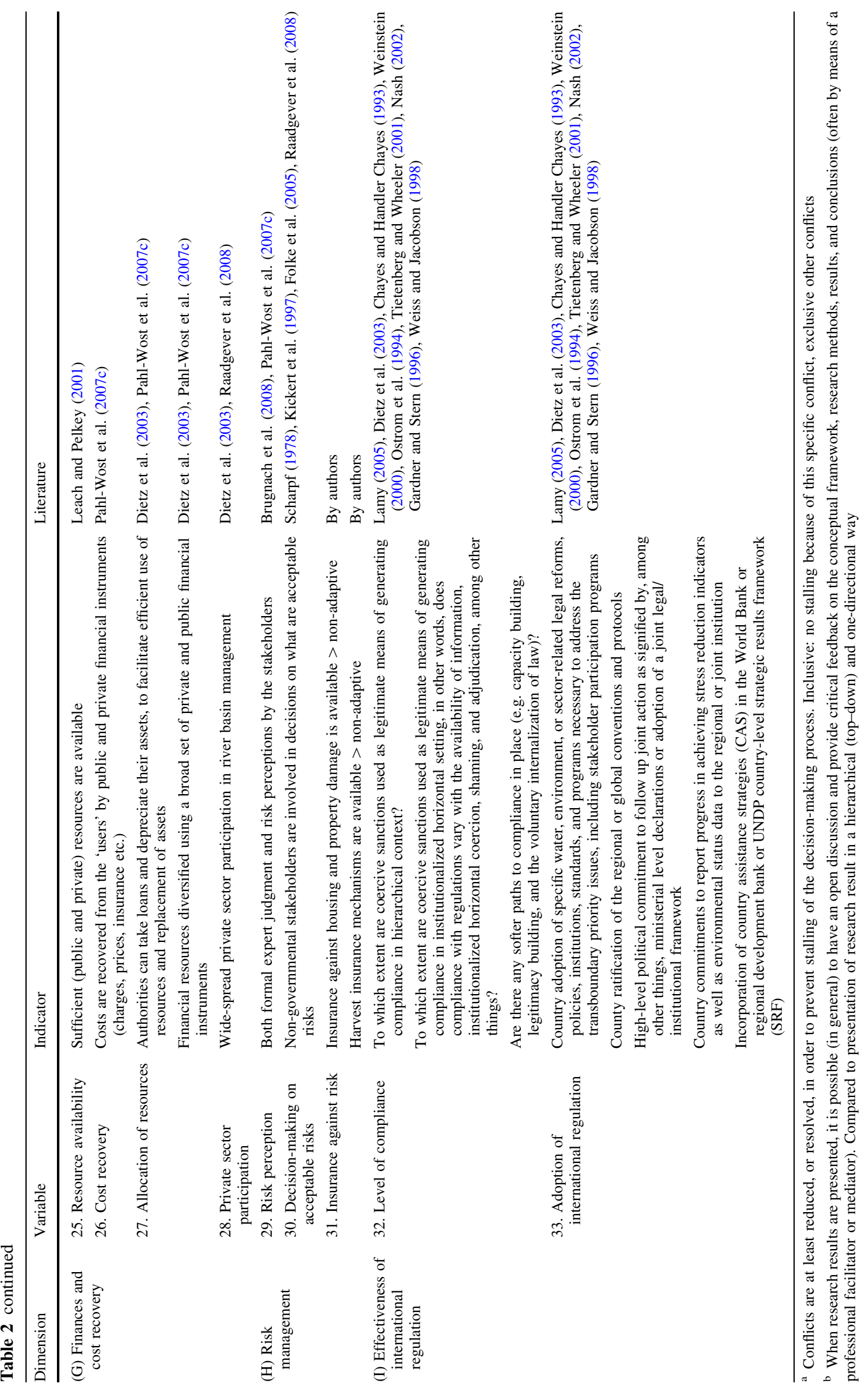




\begin{tabular}{|c|c|c|c|c|}
\hline Case-studies & 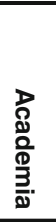 & 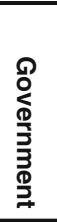 & 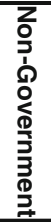 & 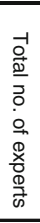 \\
\hline Lower Guadiana - Alentejo, Portugal & 4 & 2 & 4 & 10 \\
\hline Ukrainian part of Upper Tisza & 3 & 6 & 3 & 12 \\
\hline Hungarian part of Upper Tisza & 3 & 4 & 3 & 10 \\
\hline Lower Rhine - Rivierenland, Netherlands & 2 & 6 & 2 & 10 \\
\hline
\end{tabular}

Fig. 2 Overview of the number of experts (per stakeholder group) consulted in each case-study

whole questionnaire, or at least a major part of it. Moreover, with the objective of including all relevant perspectives and experiences in the case-study, the respondents group was selected as a reflection of the most important stakeholders, policymakers, water practitioners, involved scientists, private sector, and civil society. This resulted in a consultation round involving a minimum of ten experts in each case-study, reflecting perspectives from different stakeholder groups (see Fig. 2). A complete list of respondents has been provided in Huntjens et al. (2007; updated 2009).

By using standardized questionnaires, or using these questionnaires for standardized interviews, qualitative data were being collected in such a way that it was possible to compare weighted averages on each separate indicator. The weighted average has been calculated by multiplying each individual score by the weight which respondents assigned to it; the total sum of all respondents in one case-study was then divided by the total assigned weight (by adding up all weights assigned to this specific indicator). Furthermore, the level of inconsistency (standard deviation) for each variable has been calculated, next to 'Independent Samples $T$ Tests', in order to test for significant differences between the case-studies. ${ }^{6}$

The reason for developing standardized answering options in the questionnaire is that it supports a formal comparative analysis of the results. Furthermore, the questionnaire allows for assigning weights to each indicator. In this way, it is possible to aggregate multiple indicators, resulting in a score for one variable, or for aggregated variables, resulting in a score for one metavariable (e.g. dimension of variables). ${ }^{7}$

Not much work is available on comparative analyses of river basins including full range of a water management regime's complexity (Myint 2005; Wolf 1997). Many studies on IWRM are descriptive and limited to recording success or failure of single cases. The initial comparisons

\footnotetext{
${ }^{6}$ More details on statistical analyses can be found in Huntjens et al. (2007, updated 2009).

${ }^{7}$ More details can be found in Huntjens et al. (2007, updated 2009).
}

in this research will help develop and test protocols (cf. Breitmeier et al. 1996) that open the way for efforts at broader generalizations about options for institutional designs and procedures with a special emphasis on assessing what does and does not work well with respect to adaptive and integrated water management.

\section{Empirical results show general patterns in the characteristics of adaptive and integrated water management}

Based on our formal comparative analyses of the water management regimes in the four case-studies, it is possible to identify general patterns in the dimensions of AIWM. It is important to acknowledge that management regimes with the majority of variables having a weighted average closely to 2 are considered regimes that follow a pattern of configuration more closely related to AIWM. Additionally, we assume that a necessary prerequisite for being adaptive is a high degree of integration (Pahl-Wostl and Sendzimir 2005). Our results show that the case of Rivierenland appears to be the most closely related to AIWM (see Fig. 3). Moreover, the empirical results clearly show that the dimensions of AIWM are interdependent, meaning that when variables show high averages in one dimension, the variables in other dimensions of the respective case-study equally show high averages. On the other hand, when variables in one dimension show low averages, the variables in other dimensions also show low averages. This interdependency is especially evident between variables in information management, cooperation structures, and conflict resolution (see Table 3), but also a number of indicators in other variables such as in risk management and policy development and implementation. Within these dimensions, the following very significant correlations $(P \geq 0.95)$ stand out: ${ }^{8}$

- Information management (in particular joint/participative information production, consideration of uncertainties, and broad communication) shows very significant positive correlations $(P \geq 0.95)$ with cooperation structures (in particular vertical cooperation, vertical conflict resolution, and transboundary cooperation).

- Risk perceptions (in particular participative risk perceptions and participatory decision-making on what are acceptable risks) show very significant positive correlations $(P \geq 0.95)$ with information management (all variables) and with cooperation structures (in particular

\footnotetext{
8 A complete overview of correlation coefficients has been provided in Huntjens et al. (2007, updated 2009).
} 
Fig. 3 Level of Adaptive and Integrated Water Management in coping with climate-related extreme events in the four casestudies $(0=$ non-adaptive and non-integrated, 2 = adaptive and integrated). From: Huntjens et al. (2007)

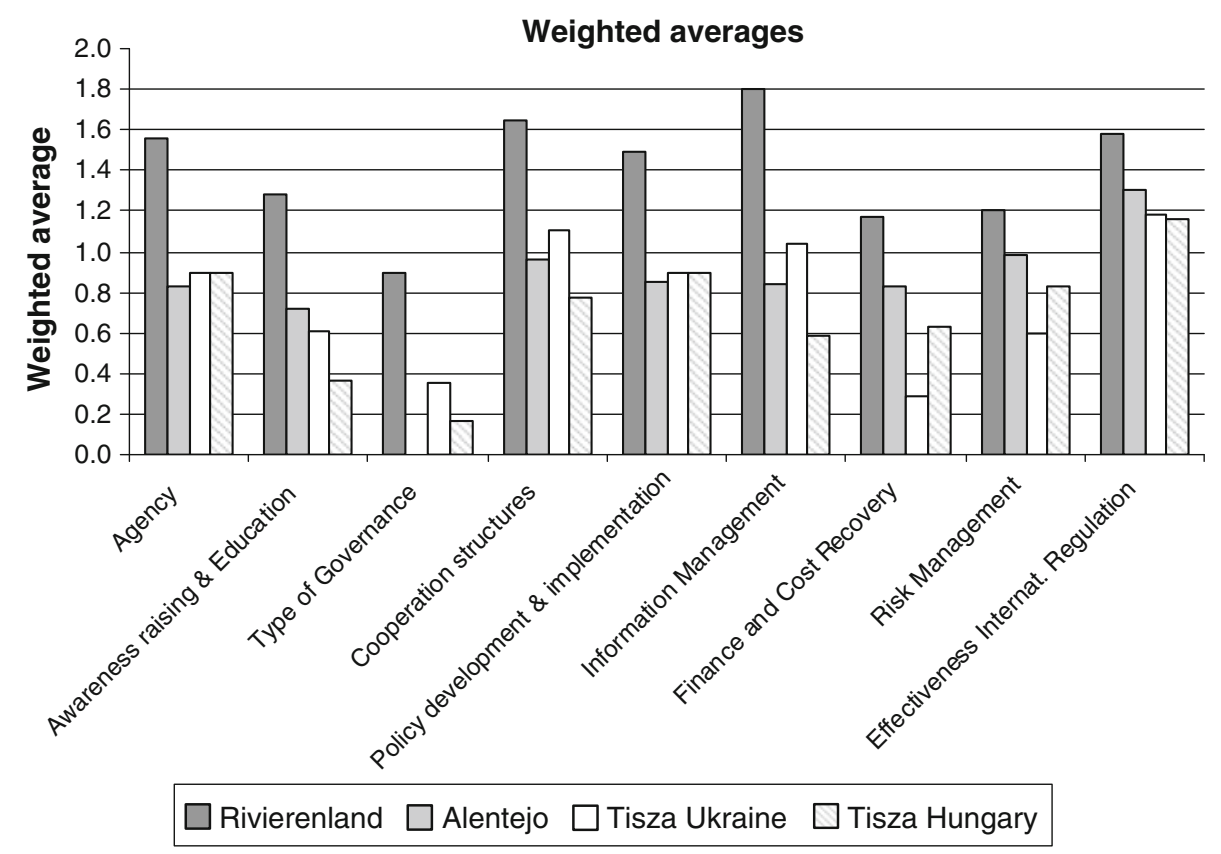

vertical cooperation, vertical conflict resolution, and transboundary cooperation).

- Consideration of possible measures shows very significant positive correlations $(P \geq 0.95)$ with bottom-up governance, stakeholder participation, implementation of policies, participative risk perceptions, and adaptive leadership.

Earlier mentioned results reveal many positive correlations between variables from different regime elements. This suggests a strong interdependence of the elements within a water management regime, and as such this interdependence is a stabilizing factor in current management regimes. For example, based on the very significant positive correlations between joint/participative information production, and vertical cooperation, transboundary cooperation, consideration of uncertainties, and broad communication, we can conclude that a lack of joint participative knowledge production is an important obstacle for vertical cooperation and conflict resolution, or vice versa. Cooperation and joint/participative knowledge production is even more important when dealing with uncertainty and change. Several authors (Olsson et al. 2006; Stubbs and Lemon 2001; Loeber et al. 2007) argue that linking different networks and creating opportunities for new interactions are critical factors for learning and nurturing integrated adaptive responses to change. Therefore, mechanisms which facilitate social learning such as coproduction (e.g. joint/participative knowledge production) and multiple stakeholder platforms are therefore being suggested as an important design principle for river basin management at different scales (Pahl-Wostl et al. 2007b). Such an institutional design principle would be an addition to the design principles developed by Ostrom (1990), which are based on long enduring local and singleuse common pool resource communities. In contrast, river basins are open resources systems on a larger scale, with a complex constellation of multiple-uses, meaning that additional, or perhaps different, design principles might be relevant.

An important hypothesis in the concept of social learning is that information management and social (cooperation) structures are interlinked (Pahl-Wostl et al. 2007a), which corresponds to the socio-cognitive theory of information systems (Hemmingway 1998). Hemmingway pays attention to the impacts of presented information on learning and action, and the centrality of the selection and organization of information to the nature of organizational forms. Our research confirms that information management and social (cooperation) structures are interlinked in the management regimes under consideration. This interdependency can be described as the socio-cognitive dimension of water management regimes. We define the sociocognitive dimension as the integrated cognitive and social properties of complex systems and related processes. These (informal or formal) learning environments are an emergent property of the interlinkage between information management and social cooperation structures and are perceived to be crucial for the adaptive governance of socio-ecological systems (see also Folke et al. 2005; PahlWostl 2005).

The earlier mentioned positive correlations provide evidence that there is a strong interdependence of the 


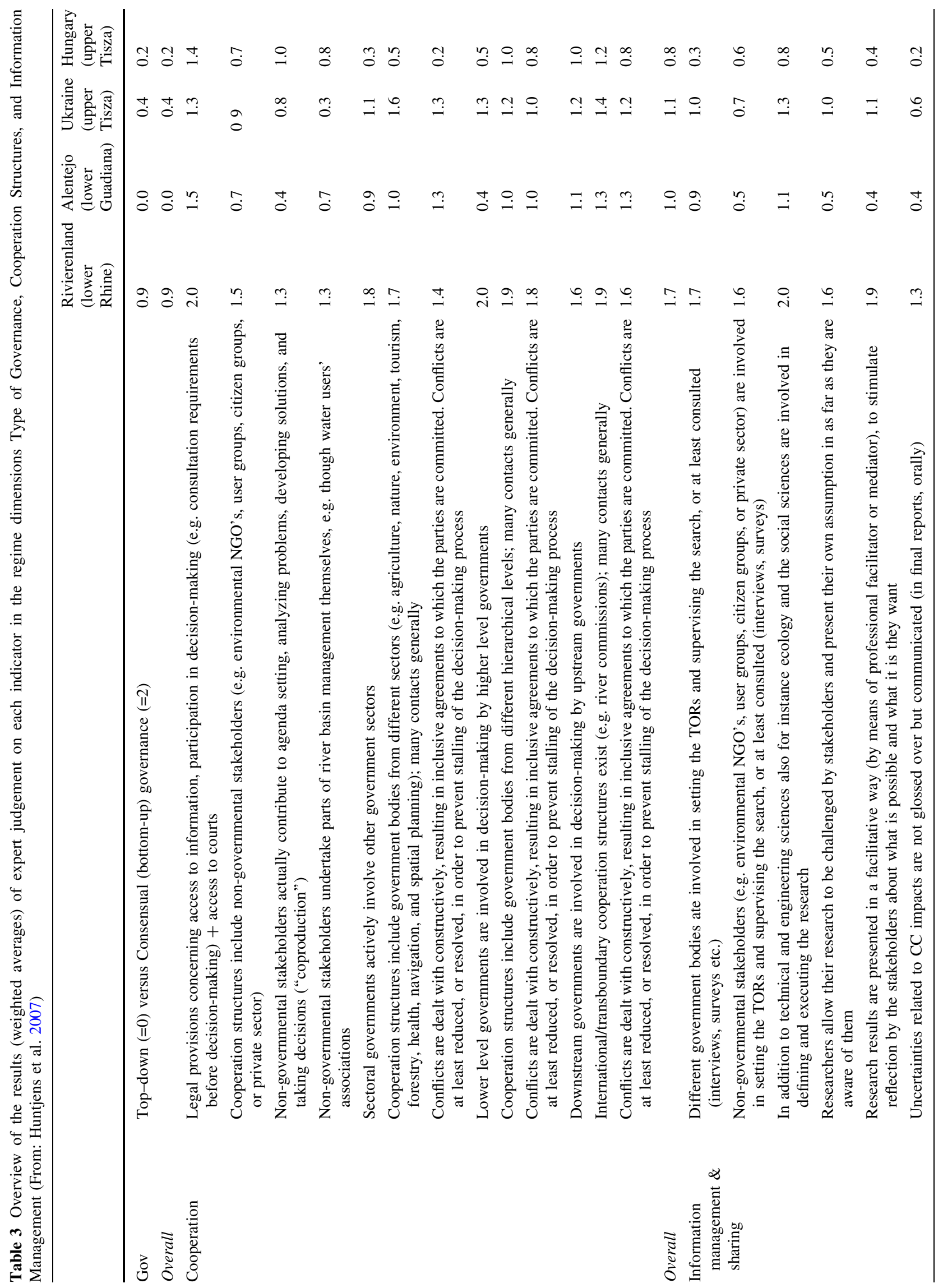




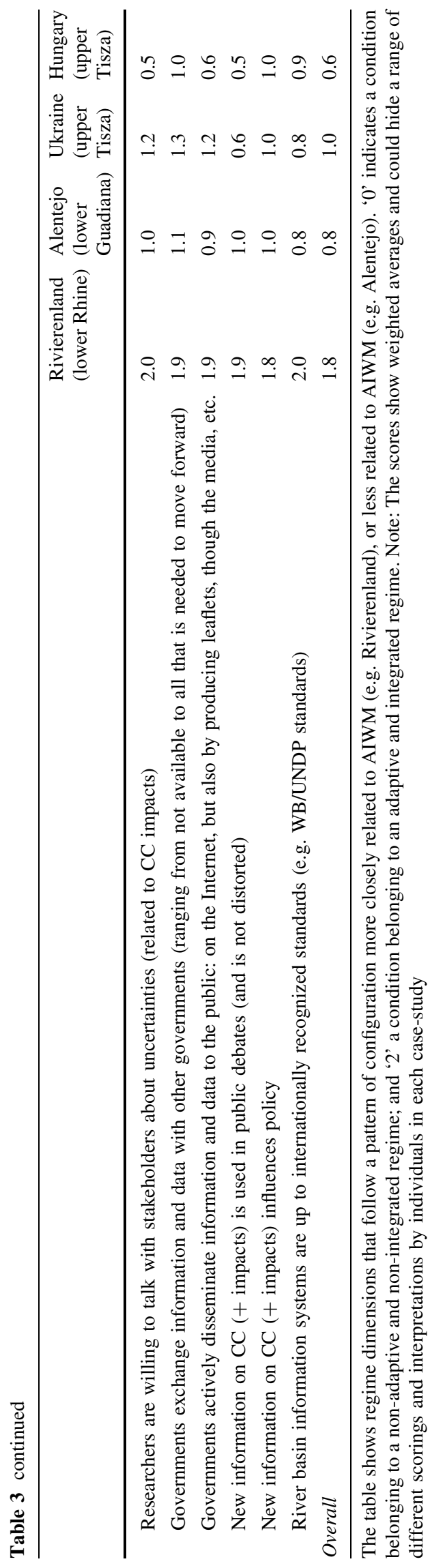

elements within a water management regime. Such interdependences may constitute stabilization of currently evolving water management regimes toward AIWM regimes. One cannot, for example, move easily from topdown to participatory management practices without changing the whole approach to information management, policy development, risk management, cooperation structures, and styles of leadership. Additional limiting factors for moving toward adaptive and integrated water management regimes are a lack of funding and capacity in current water management regimes. Lack of capacity refers to a lack of adaptive leadership, limited number of water professionals who are familiar with AIWM approaches, and limited public participation and stakeholder participation.

\section{Finding a balance between bottom-up and top-down governance in river basin management}

The weighted averages on governance suggest that bottomup governance plays not such a primary role in AIWM as earlier suggested. For example, the weighted average on governance in Rivierenland (see Table 4) indicates that there is much more top-down governance than could be expected from consensus-based decision-making, particularly since the Netherlands is well known for its consensus-based decision-making (also called the 'Poldermodel'). The fact that Rivierenland also shows a substantial degree of topdown governance is reflected in the framework for flood management (PKB Room for Rivers) in the Netherlands, which was initiated by the national government (Berenschot 2007). Nevertheless, after initiation by the national government, the framework was being further developed, and this process was much more characterized by bottom-up governance (Berenschot 2007). This bottom-up process was, among others, reflected in the document called "Advice to the parliament as regard the PKB Room for Rivers by nine civil society organizations" (LIRR 2003).

In July 2006, the Directorate-General Water in the Netherlands published a policy document (Waterkoers 2), which refers to transitions and five paradigm shifts, which it considers to be important for future water management. This report concludes that 'public and civil society are still not adequately mobilised, despite substantial investments'. In other words, a balance between bottom-up governance and top-down governance has not been found yet, if such a balance is to be found at all.

It should be emphasized that even where bottom-up governance is a useful tool, it may be usefully supplemented by the state. For example, decentralization does not exclude public control, since public and governmental authority can also be located at lower levels-e.g. 


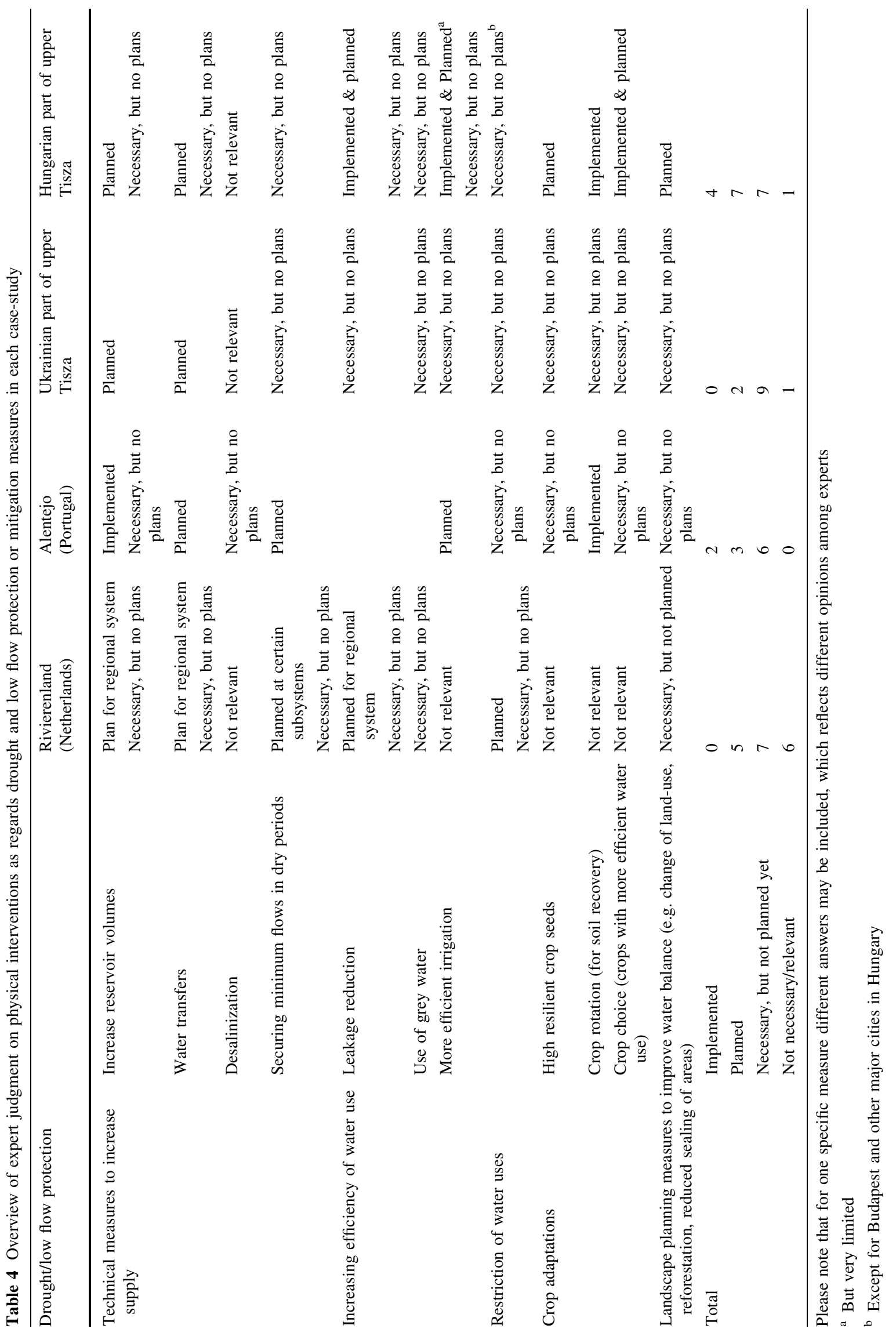


independent provinces. Carruthers and Stoner (1981) even argued that "common property resources require public control if economic efficiency is to result from their development', and they concluded that public control is needed to avoid overexploitation of resources. On the other hand, Elinor Ostrom (1990) argues that centralized control is based on assumptions concerning the accuracy of information, monitoring capabilities, sanctioning reliability, and zero costs of administration. Without valid and reliable information, a central agency could make several errors, including setting the carrying capacity or the fine too high or too low, sanctioning water users who cooperate, or not sanctioning defectors.

Acknowledging both sides of the coin, Scharpf has pointed out the importance of "bargaining in the shadow of hierarchy" (Scharpf 1997). A variety of empirical studies exemplify this claim. For instance, Bardhan (2002) has found that the state can promote bottom-up, consensual decision-making by playing an active role in the mobilization of people in local processes, it can aid in neutralizing local oligarchs, can provide funds for local initiatives, provide technical and professional services to help local capacity building, guarantee quality standards, invest in larger infrastructure, and coordinate in externalities that span more than one local government. Healey et al. (2003) demonstrate that collaborative decision-making may be promoted by strong, strategically operating (local) governments. In a case-study of a practice in the area of sustainable agriculture, Hendriks and Grin (2007) have found that "Parliament may have been inactive, but it was certainly not insignificant." It neither intervened, nor did it much to implement the recommendations, but still was important as "it provided the locus around which much discursive activity was centred, and this helped to legitimate the project."

In summary, for large-scale, complex multiple-use systems, such as river basins, this research suggests that bottom-up governance and decentralization are not a straightforward solution to water management problems. There will probably always be the need for a certain degree of top-down governance (or centralization), where a central authority has the responsibility and resources for issues like facilitation of participatory processes, setting of standards, capacity building, conflict resolution, and cooperation across boundaries. All the case-studies in this research seem to be in a process of finding a balance between bottom-up and top-down governance.

\section{Responsiveness to extreme droughts and low flow problems}

Next to comparing the level of AIWM, and identifying general patterns in the characteristics of AIWM, it is important to compare whether there are differences between the management regimes as regards measures being taken to cope with floods and droughts. After all, a higher level of AIWM is expected to result in more advanced adaptation strategies and measures to cope with (the threat of) floods and droughts. This research has labeled this outcome of a water management regime as the responsiveness to flood and drought problems.

The responsiveness of the management regimes to severe drought events in the recent years is very limited in all case-studies (see Table 4). This lack of an adequate response in all case-studies is noteworthy, since droughts have already caused enormous adverse social, economic, and environmental effects in recent years (Della-Marta et al. 2007: 252; EM-DAT 2008), and it is expected that this will become even worse due to climate change (IPCC 2007). Climate change models project more frequent and intense summer droughts across many parts of Europe, particularly in the southern part (Goodess et al. 2007; EEA 2005). This may be further exacerbated because of an increasing demand for water as a result of elevated temperatures (EEA 2005).

This research shows that the management regime confronted with the most severe water scarcity-the Alentejo case-study - is showing a poor response, at least in terms of diversity in measures, when compared to other case-studies. Despite the fact that the Alentejo region has been confronted with drought events for many decades, out of the twelve possible measures in Table 4, only two measures for dealing with droughts have been implemented up until today: (1) increasing reservoir volumes (e.g. Alqueva Reservoir) and (2) crop rotation. The Alqueva Reservoir is an extensive multipurpose project that aims at a social and economic development of the Alentejo region in the south of Portugal, by means of setting up a strategic water reserve and providing a guarantee of water supply for irrigation (110000 ha), population, and industry (EDIA 2008).

Besides crop rotation and the large-scale Alqueva reservoir, only three additional measures have been planned in the Alentejo region (water transfers, securing minimum flows, and more efficient irrigation), while six measures are being mentioned as necessary, but for which no plans have been developed. Experts in the Alentejo region indicate that much faith has been put in the water transfers of the EMFA-project, ${ }^{9}$ a project seen as a solution to all water shortages. However, these water transfers are expected to lead to serious negative environmental impacts, and even to violations of the EU Habitat Directive (Platform for

\footnotetext{
${ }^{9}$ Empreendimento de Fins Múltiplos de Alqueva (EFMA): a plan for multiple uses of the Alqueva reservoir), a project which has been partially financed by the European Investment Bank (EIB) with loans totaling EUR 135 million.
} 
Sustainable Alentejo 2005). In summary, large-scale infrastructure is not seen as a problem in the Alqueva casestudy, and as such there is also no sign of a "paradigm shift" as regards the implementation of more small-scale and non-structural measures.

Extensive studies in the Netherlands (Droogtestudie 2005, update 2008) indicate that droughts and heat waves are becoming a serious problem for many sectors, such as water transport, agriculture, and nature. Even though the problem is recognized, the political climate in the Netherlands is not ready for a policy change with regard to extreme droughts and heat waves. This political climate is represented in the Dutch National Safety Reports (Ministry of Domestic Affairs, sub-report on extreme droughts and heat waves, 2006), which concludes that the situation with respect to mitigation and prevention of extreme droughts and heat waves is not as urgent when compared to other natural threats, such as pandemics (e.g. mouth-and-foot disease) and the threat of floods. Even though Dutch society had clear warning signals before, regarding the impacts of extreme droughts, it was not enough to put drought problems high on the public or political agenda. These clear warning signals included for example the fact that agricultural production in the Netherlands is reduced by 5 to $35 \%$ because of water shortages (National Safety Reports, Ministry of Domestic Affairs, Netherlands 2006). This means an average economical damage of 180 million Euros/year, and even 1800 million Euros/year in extreme years (idem). Damage to the Dutch water transport sector goes up to 800 million Euros in extreme years (Droogtestudie 2005). During severe droughts in the Netherlands in the summer of 2005, the Dutch Government desperately launched a national ad hoc campaign to urge people to use less drinking water and less electricity. Simply because there was not enough water for public and agricultural water supply, and water temperatures were too high for abstracting cooling water from the rivers, which is necessary for electricity production. Nevertheless, in Rivierenland, the response to current and expected drought problems is poor. Experts in Rivierenland have indicated that seven measures are necessary or effective for dealing with droughts, but none of them have been implemented so far. Only for a few subsystems, there are plans for increasing reservoir volumes, water transfers, securing minimum flows in dry periods, leakage reduction, and restriction of water uses, but none of these plans have been implemented yet.

Based on the conclusions of the Dutch National Safety Reports (2006), but also based on expert judgment in this research, it is justified to conclude that the political climate does not make the time right for change. Kingdon (1995) stresses the importance of timing for initiating policy changes and opening "policy windows". He argues that significant changes are most likely when three independently operating "streams," i.e., problems, solutions, and politics, come together at critical times. In other words, even though the problem of extreme droughts in the Netherlands is being recognized to some extent (Droogtestudie 2005, update 2008), there is no window of opportunity to initiate new policy measures, since this would require, in addition to recognition of the problem, that " $a$ solution is available, and the political climate makes the time right for change, and the constraints do not prohibit actions" (Kingdon 1995).

As regard the Upper Tisza, agriculture and forestry have suffered from extensive droughts in successive years. However, the implemented and planned measures for drought and low flow protection are rather limited so far. The extreme drought events have at least initiated the development of the Hungarian Drought Strategy (2004), with support of UNCCD, although an integrated strategy at national level is not yet available (Pers. Comm. Dr. Z. Flachner, Hungarian Academy of Sciences). The present version of the national drought strategy (to be approved yet) states that drought can affect the whole of society and requires a systematic approach to mitigate its consequences. It envisages the establishment of a National Drought Committee and a Drought Fund (EEA 2006).

In the Zacarpathian Tisza, there is no literature and data available on the frequency and intensity of droughts and heat waves. If there would be a problem with severe drought events in this case-study, we can at least conclude that this problem is not being recognized up until today, or that the problem is not that severe in this case-study when compared to other case-studies. Nevertheless, the experts in this case-study indicate that nine (9) measures for drought and low flow protection are necessary, but none of them has been planned yet. As such we can conclude that this case-study is confronted with drought and low flow problems, but that the responsiveness of the management regime is almost zero.

\section{Responsiveness to (the risk of) floods}

In contradiction to the poor response to drought and low flow problems, all management regimes, except in the Alentejo region, seem to be more effective in terms of flood protection measures (see Table 5). In the Alentejo region, respondents indicate that flood problem (and flood protection) is not an issue, although it was confronted with serious flooding events (notably in 1997 and 2006).

Rivierenland shows the most advanced policy development and implementation regarding flood protection, although this policy was mainly the result of (the threat of) floods in 1993 and 1995. As such its policy is a response 


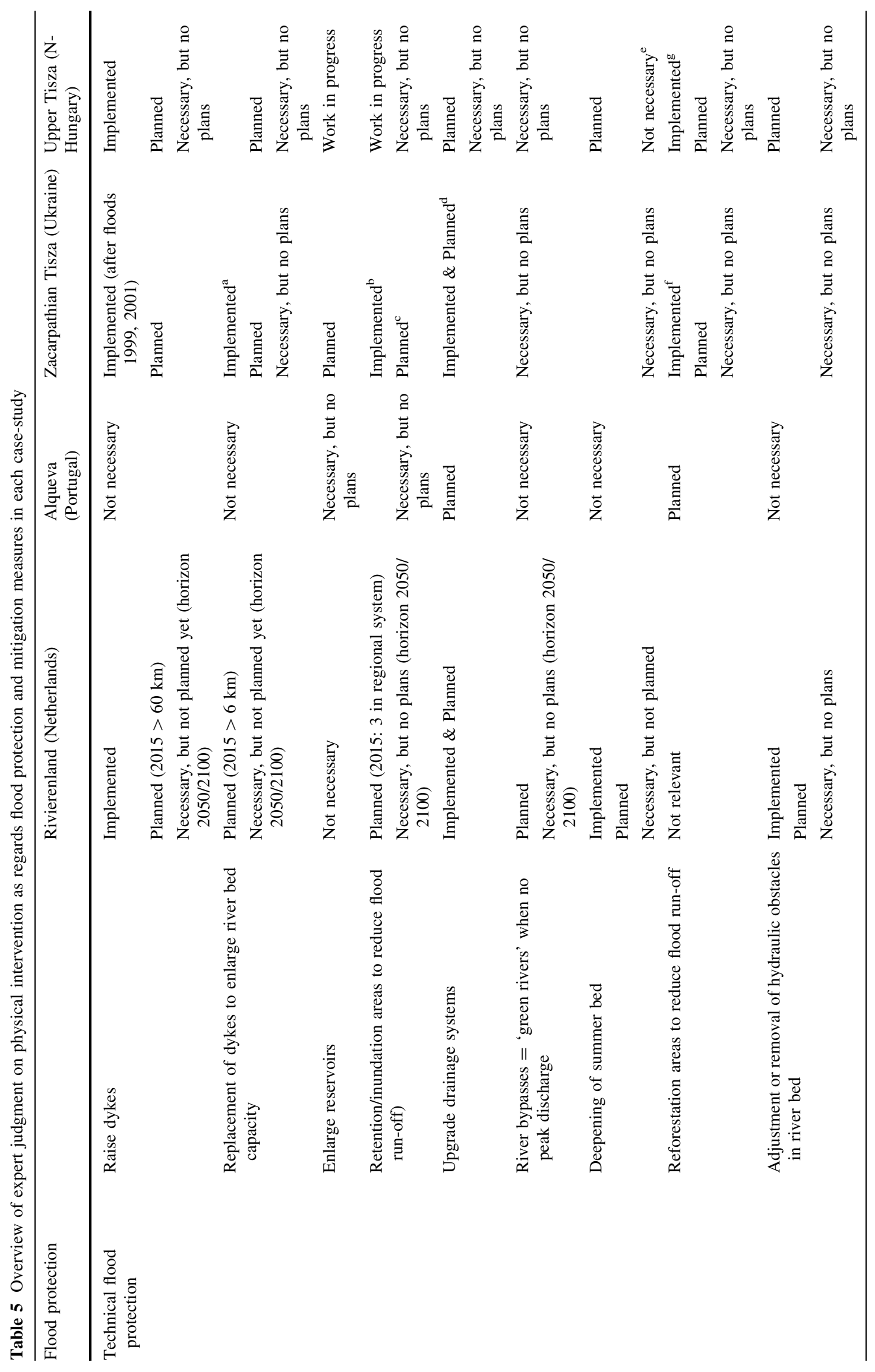




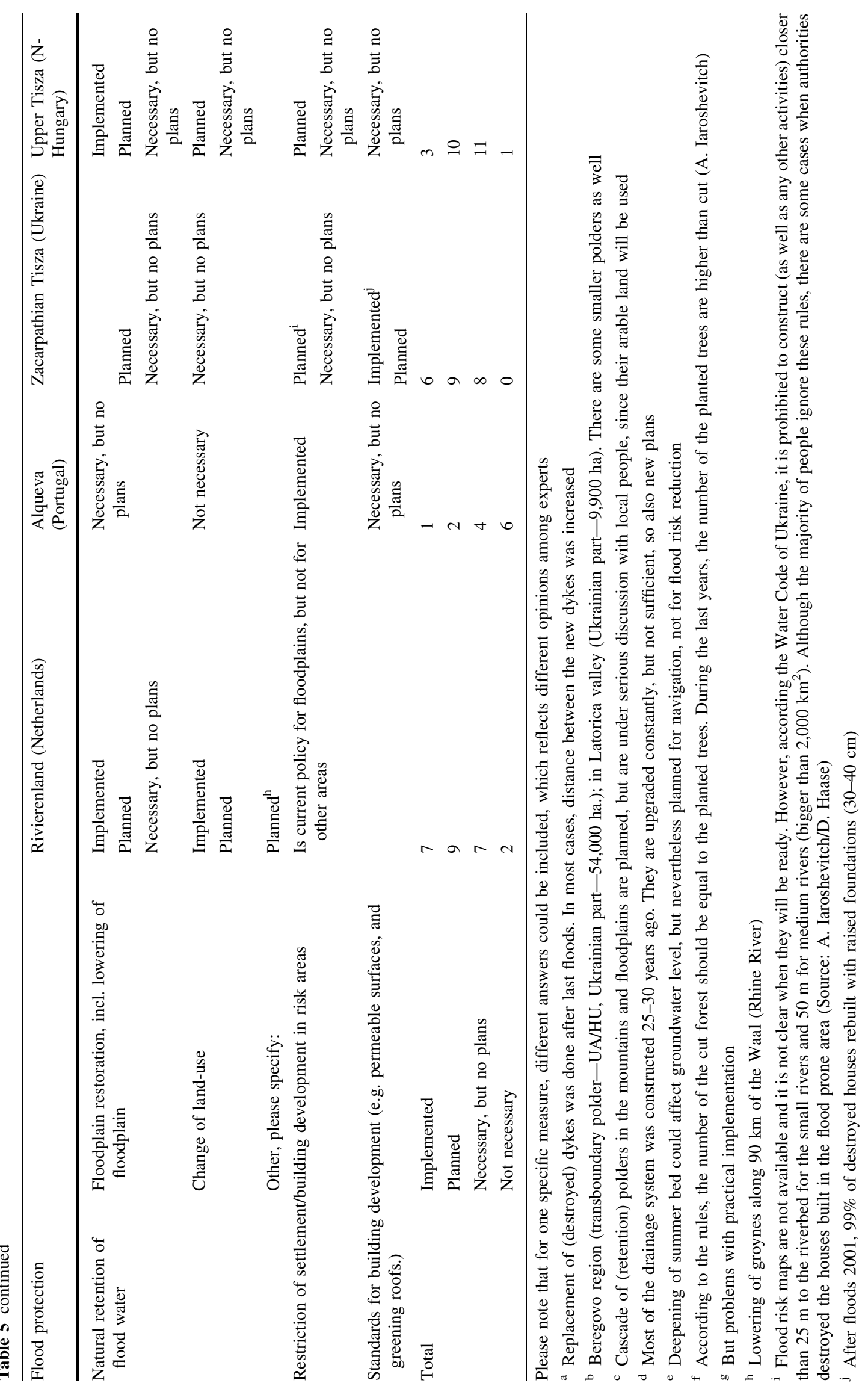


due to extreme events in the past. These extreme events created political momentum for developing new flood protection policy, including climate change (scenarios) and structural and non-structural measures for flood protection. Also in both Tisza case-studies, recent floods have increased political momentum for planning new flood protection measures, although this has started a decade later, mainly due to the floods of 2005.

The revised State Program for Flood Protection in the Ukraine has been planning new flood protection measures in the period 2002-2010, and after re-assessment of what is effective (which allows at the same time for reallocation of resources), there will be a new implementation plan for the period 2010-2015.

The Zacarpathian Tisza seems to be quite effective in dealing with floods, at least in terms of policy development and implementation. However, the revised State Program for Flood Protection does not include any climate change scenarios (Pers. Comm. Dr. A. Iaroshevitch, Ukrainian Center of Environmental and Water Projects). In other words, there is a serious risk that the implemented and planned flood protection measures are not effective enough for dealing with increased frequency and intensity of floods in the coming decades. On the other hand, in Hungary, there are a number of research programmes (Hungarian MoEW 2005; VAHAVA 1 and 2$)^{10}$ which are trying to define the scale of possible impacts of climate change. However, since there is no agreement yet on these climate change scenarios, it has not been included in current Hungarian water policy. Jolánkai (2005) concludes that, based on the analysis of climate change and precipitation scenarios, higher floods than observed so far may occur, needing upgraded flood-control strategies (with the meaning that presently contemplated strategies, such as the VTT $^{11}$ in Hungary, may not be sufficient to cope with floods).

The Dutch water policy (Ministry of Transport, Public Works and Water Management 2000) recognizes that in the coming years increasing water levels in the rivers and the accelerated rise in sea levels will mean that technical measures, such as raising dykes, will no longer be

\footnotetext{
10 To tackle the increasing risk stemming from global climate change, and to support the founding of the domestic climate policy the Hungarian Ministry of Environment and Water together with the Hungarian Academy of Sciences launched a common research programme named VAHAVA, "The domestic effects of global climate change, and the answers to be given to the challenge". Primary aim of this project was the preparation to the potential negative and positive effects of climate change, harm reduction, prevention and advancement of restoration.

11 The new Vásárhelyi Plan (abbreviated in Hungarian as VTT), adopted on the 15 of October, 2003, envisaged the development of six emergency reservoirs along the Upstream- and Middle Tisza sections to enhance the level of flood safety in the region.
}

sufficient. The policy is to allow more space for water. In order to prevent floods, rivers are allowed to expand into side channels and wetland areas. Greater emphasis is also placed on managing water levels rather than keeping the water out. This paradigm shift can also be observed by the current implementation of non-structural measures such as flood insurance, flood zoning restrictions, land-use management, economic incentives, public information, and community education (Raadgever and Mostert 2005). Nonstructural measures are intended to modify flood susceptibility and flood impact. Also, voluntary measures by land users (e.g. change of land-use) are now starting to come into practice.

\section{Discussion and conclusions}

Comparing the responsiveness of the management regimes to drought and low flow problems and their responsiveness to flood problems suggests that the former is considerably lower than the latter. Drawing on the discussion in the preceding two sections, part of the explanation may be that flood problems are more directly perceived and experienced by not only experts and policy makers, but also by the wider public, creating a 'policy window' through public pressure (which may induce responses) and concern (which may help politicians to legitimize responses). This research shows that in a basin where one type of extreme is dominant-like droughts in the Alqueva (Portugal) and floods in Rivierenland (Netherlands) - the potential impacts of other extremes are somehow ignored or not perceived with the urgency they might deserve. Within this context, it is important to acknowledge the importance of a critical awareness threshold, prior to the opening of a policy window. We argue that such a critical awareness threshold is directly related to joint/participative information production, as a necessary prerequisite for reaching a critical awareness threshold concerning the impacts of climate change and the need to take anticipatory action. However, such a policy window will only appear if the other conditions, as suggested by Kingdon (1995), have been met. For example, based on the conclusions of the Dutch National Safety Reports (2006), but also based on expert judgment in this research, it is justified to conclude that the political climate in the Netherlands does not make the time right for change as regards the development of a new and innovative drought policy.

In contrast to the poor responses to drought and low flow problems, a higher level of AIWM seems to result in more adequate responses to flood problems, at least in terms of flood protection or mitigation measures. The response of more adaptive and integrated regimes is characterized by a higher diversity in the type of measures being implemented 
or planned, including more attention for non-traditional measures, such as green by-passes and natural retention of flood water. The higher diversity in response measures indicates that horizons of possibility are being expanded, which corresponds to the concept of triple loop learning developed by Hargrove (2002:118). Case-studies showing a lower level of AIWM, for example the Lower Guadiana in Portugal, merely improve performance (e.g. increase reservoir volumes) without changing guiding assumptions or without taking entirely alternative actions into account. This involves doing things better without necessarily examining or challenging underlying beliefs and assumptions (Kahane 2004). These types of actions correspond to single loop learning (Hargrove 2002). In other words, our research indicates that case-studies showing a higher level of AIWM seem to have higher levels of learning in terms of its physical interventions. However, this observation needs to be further investigated by scrutinizing the policy responses of the management regimes in terms of different levels of policy learning (Grin and Loeber 2007). Nevertheless, this first observation is in line with our working hypothesis that AIWM requires many instances of social learning to implement and sustain innovative approaches (Pahl-Wost et al. 2007c). Additionally, our research shows that uncertainty related to climate change is often considered as an excuse for not taking action. An exception is case-study Rivierenland where the Room for Rivers-policy is taking into account climate change scenarios, besides other types of uncertainty, such as political and technological uncertainties (Huntjens et al. 2007, update 2009). Hence, we argue that management regimes having the intention to constructively deal with uncertainty are doing this by the active involvement of a diverse group of stakeholders in policy-making and by means of joint/participative information production. Moreover, we have also seen that some uncertainties might be overcome by conducting policy experiments, such as the management experiment near Avelingen (in the Netherlands) for testing alternative designs for the processes of developing integrated flood management plans (Huntjens et al. 2007, update 2009).

In terms of the current status of physical interventions in the river basin, the responsiveness of all case-studies to deal with extreme drought events is poor, and we have not found conclusive evidence that a higher level of AIWM creates a better response to drought and low flow problems. However, it is important to acknowledge that a regime with a higher level of AIWM may not have achieved its projected outcomes yet, since there normally is time lag between policy development and factual implementation. Our research provides evidence that drought response/ adaptation seems to be slower than responsiveness related to floods. This might be explained by different risk perceptions (Green et al. 2007; Neuvel 2004; De Hollander and Hanemaaijer 2003; Lijklema 2001) and differences in the availability of solutions. We also suggest that these differences might be explained by the nature of the problem itself, whereas flood management is determined by safety concerns, drought management is determined by water scarcity and related problems in the allocation of water resources. Moreover, we argue that the threat of floods is often perceived as more threatening and acute than the threat of droughts, since the latter is spread out of longer time periods and consequences are often felt indirectly. Moreover, in the Netherlands, the risk of drought problems and water scarcity caused by climate change is not acknowledged by all stakeholders, as indicated by the experts in this research, but also by Neuvel (2004). Combining the poor response to drought and low flows problems with the enormous social, economic, and environmental effects in recent years, it is justified to support Milligan's statement that droughts and heat waves are the developed world's hidden disaster (Milligan 2004), and in this case the hidden disaster of Europe. We argue that a regime element such as joint/participative information production is crucial for identifying hidden disasters and for reaching a critical awareness threshold for initiating a policy window. From this perspective, it is expected that a regime with a higher level of AIWM is more responsive to the threat of new or hidden disasters than a less adaptive regime. This seems to be confirmed by case-study Rivierenland, since they have been confronted with serious droughts only recently, but the first steps are being taken as regards developing a nationwide adaptation strategy for this specific problem, expected to be published in 2012 (Pers. Comm. Luit-Jan Dijkhuis, Directorate-General Water, Netherlands). However, the current political climate might be a limiting factor for consolidating a comprehensive strategy.

Besides the earlier explanations for the different responses to flood and drought problems, we also argue that looking at physical interventions provides an incomplete picture of the capabilities or outputs of a water management regime. Hence, drawing conclusions merely based on the physical response would be premature, and we argue that a management regime with a higher level of AIWM might be more productive in terms of management interventions than in terms of physical interventions. In other words, our research provides valuable insights as regards the research design for analyzing complex multilevel governance systems. One of the limitations of the research design in this paper is the narrow definition of the outputs of a management regime, being defined as physical interventions in the river basin. Apart from the physical intervention in the water system, a regime's performance could and should also be measured by its 'non-physical' measures, such as awareness campaigns, measures for improving information management and exchange, 
cooperation structures, and insurance mechanisms. In principle, these are measures which target at all the elements of a water management regime, and even could target at (changing) the formal institutional setting (e.g. European Directives and national or regional water laws). This means that there could be many nonlinear feedback loops within the regime itself, and the regime is in that sense creating its own enabling environment. Especially in regimes with a higher level of AIWM, the formal institutional setting is being altered by the demand for governance as regards (new developments in) water-related problems, such as the impacts of climate change. Examples include the Dutch National Water Agreement (Bestuursakkoord Water 2002), leading toward the start of implementing the Room for Rivers-policy (PKB Ruimte voor de Rivier 2006), and the Hungarian National Drought Strategy (2004). Therefore, in succeeding research of the EU Newater project, we will focus on climate change adaptation strategies, being defined as an output of the management regime. These strategies will be assessed by looking at physical AND management interventions. Additionally, the outputs of a management regime will be evaluated in terms of different levels of policy learning (Hall 1988; Bennett and Howlett 1992; Sanderson 2002; Huitema and Meijerink 2007; Grin and Loeber 2007). We believe that such a research design, thanks to lessons learned in this research, is better equipped for analyzing the adaptive capacities of water management regimes.

Acknowledgments We would like to thank the local stakeholders and experts in the four case-studies, in the Netherlands, Portugal, Hungary, and Ukraine. The work was prepared under contract from the European Commission, Contract no. 511179 (GOCE), Integrated Project in PRIORITY 6.3 Global Change, and Ecosystems in the 6th EU framework programme: the NeWater-project (http://www. newater.info). Furthermore, we thank two anonymous reviewers for the very useful comments to improve the quality of the paper.

Open Access This article is distributed under the terms of the Creative Commons Attribution Noncommercial License which permits any noncommercial use, distribution, and reproduction in any medium, provided the original author(s) and source are credited.

\section{References}

Adger WN, Arnell NW, Tompkins E (2005) Successful adaptation to climate change across scales. Glob Environ Change 15(2):77-86

Bardhan P (2002) Decentralization of governance and development. J Econ Perspect 16(4):185-205

Bennett CJ, Howlett M (1992) The lessons of learning: reconciling theories of policy learning and policy change. Policy Sci 25:275294

Berenschot (2007) Procesevaluatie totstandkoming PKB Ruimte voor de Rivier. Bureau Berenschot, in samenwerking met de faculteit Technische Bestuurskunde van TUDelft. In: opdracht van het ministerie van Verkeer en Waterstaat
Berg-Schlosser D, De Meur G, Rihoux B, Ragin CC (2008) Qualitative comparative analysis (QCA) as an approach. In: Rihoux B, Ragin CC (eds) Configurational comparative methods. Qualitative comparative Analysis (QCA) and related techniques. Sage, Thousand Oaks, pp 1-18

Bos B, Grin J (2008) Doing reflexive modernization in pig husbandry: the hard work of changing the course of a river. Sci Technol Human Values 33(4):480-507

Brannstrom C, Clarke J, Newport M (2004) Civil society participation in the decentralisation of Brazil's water resources: assessing participation in three states. Singap J Trop Geogr 25(3):304-321

Breitmeier H, Levy MA, Young OR, Zürn M (1996) The international regimes database as a tool for the study of international cooperation. Working paper WP-96-160, International Institute for Applied Systems Analysis

Brugnach M, Dewulf A, Pahl-Wostl C, Taillieu T (2008) Towards a relational concept of uncertainty: about knowing too little, knowing too differently, and accepting not to know. Ecol Soc 13(2):30 [online]

Carruthers I, Stoner R (1981) Economic aspects and policy issues in groundwater development. World Bank staff working paper No. 496, Washington, DC

Chayes A, Handler Chayes A (1993) On compliance. Int Organ 47(2):175-205

De Hollander AEM, Hanemaaijer AH (eds) (2003) Nuchter omgaan met risico's. (MNP-RIVM). Bilthoven: RIVM Rapport 2517047/ 2004

de Leon P (1998) Models of policy discourse: insights versus prediction. Policy Stud J 26(1):147-161

Della-Marta PM, Luterbacher J, von Weissenfluh H, Xoplaki E, Brunet M, Wanner H (2007) Summer heat waves over western Europe 1880-2003, their relationship to large-scale forcings and predictability. Clim Dyn 29:251-275

Dietz T, Ostrom E, Stern PC (2003) The struggle to govern the commons. Science 302:1907-1912

Dube D, Swatuk LA (2002) Stakeholder participation in the new water management approach: a case study of the Save catchment, Zimbabwe. Physics and Chemistry of the Earth, 27, Pergamon/Elsevier, 867-874

EDIA (2008) EDIA's website, http://www.edia.pt

EM-DAT (2008) The OFDA/CRED international disaster databasehttp://www.emdat.net-Université Catholique de LouvainBrussels-Belgium

European Environment Agency (2007) Climate change and water adaptation issues. EEA Technical report No 2/2007

Folke C, Hahn T, Olsson P, Norberg J (2005) Adaptive governance of social-ecological systems. Annu Rev Environ Resour 30:8.18.33

Fowler HJ, Blenkinsop S, Tebaldi C (2007) Linking climate change modelling to impacts studies: recent advances in downscaling techniques for hydrological modeling. Int J Climatol 27(12): $1547-1578$

Gardner GT, Stern PC (1996) Environmental problems and human behavior. Allyn and Bacon, Needham Heights

Giddens A (1986) The constitution of society: outline of the theory of structuration, University of California Press; Reprint edition (January 1, 1986) ISBN 0-520-05728-7

Goodess CM, Hall J, Best M, Betts R, Cabantous L, Jones PD, Kilsby CG, Pearman A, Wallace CJ (2007) Climate scenarios and decision making under uncertainty. Built Environ 33(1):10-30

Green CH, Tunstall SM, Fordham MH (2007) The risks from flooding: which risks and whose perception? Disasters 5(3):227236

Grin J, Loeber A (2007) Theories of policy learning: agency, structure and change, chap 15. In: Fischer F, Miller GJ, Sidney MS (eds) Handbook of public policy analysis. Theory, politics, and 
methods. CRC Press/Taylor \& Francis Group, USA/UK, pp 201219

Grin J, Felix F, Bos B, Spoelstra S (2004) Practices for reflexive design: lessons from a Dutch programme on sustainable agriculture. Int J Foresight Innova Pol 1(1-2):146-169

Hall PA (1988) Policy paradigms, social learning and the state. A paper presented to the International Political Science Association, Washington, DC

Hargrove R (2002) Masterful coaching. Revised Edition

Healey P, Magalhaes C, Madanipour A, Pendlebury J (2003) Place, identity and local politics: analyzing initiatives in deliberative governance. In: Maarten H, Henk W (eds) Deliberative policy analysis: understanding governance in the network society. Cambridge University Press, Cambridge, pp 60-88

Hendriks CM, Grin J (2007) Contextualising reflexive governance: the politics of dutch transitions to sustainability. J Environ Pol Plan 9(3-4):1-17

Hooghe L, Marks G (2003) Unraveling the central state, but how? Types of multi-level governance. Am Poli Sci Rev 97(2):233-243

Huisman P, de Jong J, Wieriks K (2000) Transboundary cooperation in shared river basins: experiences from the Rhine, Meuse and North Sea. Water Pol 2:83-97

Huitema D, Meijerink S (2007) Understanding and managing water transitions: a policy science perspective. Paper presented to the Amsterdam Conference on Earth System Governance, Amsterdam, the Netherlands, 24-26 May 2007

Huitema D, Mostert E, Egas W, Moellenkamp S, Pahl-Wostl C, Yalcin R (2009) Adaptive water governance: assessing the institutional prescriptions of adaptive (co-)management from a governance perspective and defining a research agenda. Eco Soc 14(1):26 [online] URL: http://www.ecologyandsociety.org/ vol14/iss1/art26/

Huntjens P, Pahl-Wostl C, Grin J (2007) Formal comparative analysis of adaptive capacity of water management regimes in four European sub basins, deliverable 1.7.9a of the NeWater project, Institute of Environmental Systems Research, University of Osnabruck

IFRC (2008) World Disasters Report 2007-tackling discrimination in disasters, International Federation of Red Cross and Red Crescent Societies, 12 December 2007

Imperial MT (1999) Institutional analysis and ecosystem-based management: the institutional analysis and development framework. Environ Manag 24:449-465

IPCC (2007) Climate change 2007: the physical science basis. Summary for policymakers. Contribution of Working Group I to the Fourth Assessment Report of the Intergovernmental Panel on Climate Change

Jolánkai G (2005) The Tisza river project real-life scale integrated catchment models for supporting water- and environmental management decisions. (Contract No: EVK1-CT-2001-00099). Final report of the project for the overall duration: 01 January 2002-31 December 2004. Sect. 6

Jupille J, Caporaso J (1998) States, agency, and rules-the European union in global environmental politics. In: Rhodes C (ed) The European Union in World Community, Lynne Rienner, Boulder, pp 213-229

Kahane A (2004) Solving tough problems: an open way of talking, listening, and creating new realities. Berrett-Koehler, San Francisco

Kerr J (2007) Watershed management: lessons from common property theory. Int J Commons 1(1):89-109

Kettl DF (2000) The transformation of governance: globalization, devolution, and the role of government. Public Adm Rev 60:488-497

Kickert WJM, Kleijn EH, Koppenjan JFM (1997) Managing complex networks, strategies for the public sector. Sage, London
Kingdon JW (1995) Agendas, alternatives, and public policies. Harper Collins, New York

Lamy SL (2005) Contemporary mainstream approaches: neo-realism and neoliberalism, chap 9. In: Baylis J, Smith S (eds) The globalization of world politics: an introduction to international relations, 3rd edn. Oxford University Press, Oxford, p 215

Lankford BA, Hepworth N (2006) The cathedral and the bazaar: centralised versus decentralised river basin management. Workshop 4: "Benefits and Responsibilities of Decentralised and Centralised Approaches for Management of Water and Wastewater". World Water Week 2006. Stockholm International Water Institute

Leach WD, Pelkey NW (2001) Making watershed partnerships work: a review of the empirical literature. J Water Resour Plan Manag 127:378-385

Lebel L, Foran T, Garden P, Manuta JB (2008) Adaptation to climate change and social justice: challenges for flood and disaster management in Thailand. Book chapter in Earth CC in Water Sector, 2008

Lijklema S (2001) Water beheren en communiceren. Een studie naar het publieke draagvlak voor het waterbeheer in Nederland. Proefschrift. Wageningen Universiteit, Wageningen

LIRR (2003) Meer waarden met een robuuste rivierruimte-Veiligheid, ruimtelijke kwaliteit en sociaal- economische vitaliteit. Advies inzake de PKB Ruimte voor de Rivier van negen maatschappelijke belangenorganisaties, verenigd in de Landelijke Initiatiefgroep Ruimte voor de Rivier (LIRR)

Loeber A, van Mierlo B, Grin J, Leeuwis C (2007) The practical value of theory: conceptualizing learning in pursuit of sustainable development', chap 3. In: Wals A, van der Ley T (eds) Social learning towards a sustainable world. Wageningen UP, Wageningen, pp 83-97

Marty F (2001) Managing international rivers: problems, politics and institutions. Peter Lang, Bern

McCay BJ (2002) In: Ostrom E et al (eds) The drama of the commons, committee on the human dimensions of global change, National Research Council, National Academy Press, Washington, DC, pp 361-402

Milligan J (2004) Heatwaves: the developed world's hidden disaster, Techn Ber, International Federation of Red Cross and Red Crescent, World Disasters Report

MoEW (Hungarian Ministry of Environment, Water) (2005) The fourth national communication of the republic of Hungary on climate change, 2005. KvVM, Budapest

Myint T (2005) Strength of "weak" forces in multilayer environmental governance: cases from the Mekong and Rhine River Basins. Indiana University, Bloomington, p 203

Nash J (2002) In: Dietz T, Stern PC (eds) New tools for environmental protection: education, information and voluntary measures, National Academy Press, Washington, DC, pp 235-252

Neuvel JMM (2004) Wateroverlast en Watertekort: percepties op risico's en consequenties voor de ruimtelijke ordening. RIVM rapport 500023002/2004

Olsson P, Gunderson LH, Carpenter SR, Ryan P, Lebel L, Folke C, Holling CS (2006) Shooting the rapids: navigating transitions to adaptive governance of social-ecological systems. Ecol Soc 11(1): 18

Ostrom E (1990) Governing the commons: the evolution of institutions for collective action. Cambridge University Press, New York (The Political Economy of Institutions and Decisions)

Ostrom V (1993) Public choice 77:163

Ostrom E (1996) Crossing the great divide: coproduction, synergy, and development. World Dev 24(6):1073-1087

Ostrom E (2001) Vulnerability and polycentric governance systems, in: newsletter on the international human dimensions program on global environmental change. No. 3 
Ostrom E (2005) Understanding institutional diversity. Princeton University Press, Princeton

Ostrom E, Gardner R, Walker J (eds) (1994) Rules, games, and common-pool resources. Univ. of Michigan Press, Ann Arbor

Pahl-Wost C, Kabat P, Moeltgen J (eds) (2007c) Requirements for adaptive water management-Coping with complexity and uncertainty, Springer. ISBN 978-3-540-75940-9

Pahl-Wostl C (2007) Transition towards adaptive management of water facing climate and global change. Water Resour Manage 21(1):49-62

Pahl-Wostl C, Sendzimir J (2005) The relationship between IWRM and adaptive water management, NeWater Working Paper No 3

Pahl-Wostl C, Sendzimir J, Jeffrey P, Aerts J, Berkamp G, Cross K (2007a) Managing change toward adaptive water management through social learning. Eco Soc 12(2): 30. [online] URL: http://www.ecologyandsociety.org/vol12/iss2/art30/

Pahl-Wostl C, Craps M, Dewulf A, Mostert E, Tabara D, Taillieu T (2007b) Social learning and water resources management. Ecol Soc 12:5. [online] URL: http://www.ecologyandsociety.org/ vol12/iss $2 /$ art5/

Platform for Sustainable Alentejo (2005) The Alqueva dam-How the EIB helped to finance environmental destruction in Portugal. Platform for Sustainable Alentejo (CPADA, CEAI, FAPAS, GEOTA, LPN, Quercus, SPEA), in cooperation with Friends of the Earth International and CEE Bankwatch Network

Raadgever GT, Mostert E (2005) Transboundary river basin management-State-of-the-art review on transboundary regimes and information management in the context of adaptive management, Deliverable 1.3.1 of the NeWater project, RBA Centre, TU Delft

Raadgever GT, Mostert E, Kranz N, Interwies E, Timmerman JG (2008) Assessing management regimes in transboundary river basins: do they support adaptive management? Ecol Soc 13(1): 14. [online] URL: http://www.ecologyandsociety.org/vol13/iss1/ art14/

RIZA (2007) Aard, ernst en omvang van watertekorten in Nederland, Eindrapport Droogtestudie. RIZA- rapport 2005.016; ISBN 9036957230

Rondinelli D, Cheema S, Nellis JR (1983) Decentralization in developing countries: a review of recent experience, world bank staff working paper no. 581. The World Bank, Washington, DC

Sanderson I (2002) Evaluation, policy learning and evidence-based policy making. Public Adm 80(1):1-22

Savenije HG, van der Zaag P (2000) Conceptual framework for the management of shared river basins; with special reference to the SADC and EU. Water Pol 2:9-45
Scharpf FW (1978) Interorganizational policy studies: issues, concepts and perspectives. In: Hanf KI, Scharpf FW (eds) pp 345370

Scharpf FW (1997) Games real actors play: actor-centered institutionalism in policy research, 3rd edn. Westview Press, Boulder

Steel BS, Weber E (2001) Ecosystem management, decentralization, and public opinion. Global Environ Change 11:119-131

Stern PC (1991) Policy Sci 24:99

Stirling A (2006) Analysis, participation and power: justification and closure in participatory multi-criteria analysis. Land Use Policy 23(1):95-107

Stubbs M, Lemon M (2001) Learning to network and network to learn: facilitating the process of adaptive management in a local response to the UK's National Air Quality Strategy. Environ Manage 27:321-334

Sumberg J, Okali C (2006) Tomatoes, decentralization and environmental management in Brong Ahafo, Ghana. Soc Nat Resour 19:19-31

Tietenberg T, Wheeler D (2001) In: Folmer H, Landis Gabel H, Gerking S, Rose A (eds) Frontiers of environmental economics, Elgar, Cheltenham, pp 85-120

Voss JP, Kemp R (2005) Reflexive governance for sustainable development. Incorporating feedback in social problem-solving, paper for ESEE conference, June 14-17, 2005, Lisbon

Voss JP, Kemp R, Bauknecht D (2006) Reflexive governance: a view on the emerging path. In: Voss JP, Bauknecht D, Kemp R (eds) Reflexive governance for sustainable development. Edward Elgar, Cheltenham, pp 419-437

Wailand WJ (2006) Evolving strategies for twenty-first century natural resource problems - adaptive governance and water conflict: new institutions for collaborative. In: Scholz JT, Stiftel B (eds) Resources for the Future Press, Washington, DC, pp ix, 274

Weinstein MS (2000) Georgetown Int. Environ Law Rev 12:375 (2000)

Weiss E, Jacobson H (eds) (1998) Engaging countries: strengthening compliance with international environmental agreements. MIT Press, Cambridge

Wendt A (1995) Anarchy is what states make of it: the social construction of power politics. In: Kratochwil F, Mansfield E (eds) International organization: a reader, p 87

Willis KJ, Whittaker RJ (2002) Science 295:1245

Wolf AT (1997) International water conflict resolution: lessons from comparative analysis. Water Resour Dev 13(3):333-356

Young OR (2002) The institutional dimensions of environmental change: fit, interplay, and scale. MIT Press, Cambridge 